\title{
Developmental Changes in Rat Cardiac DNA, RNA and Protein Tissue Base: Implications for the Interpretation of Changes in Gene Expression
}

\author{
Maurice J. B. van den Hoff, Ronald H. Lekanne Deprez, Marisol Monteiro, \\ Piet A. J. de Boer, Rob Charles and Antoon F. M. Moorman \\ Department of Anatomy and Embryology, University of Amsterdam, Academic Medical Center, \\ Meibergdreef 15, 1105 AZ Amsterdam, The Netherlands
}

(Received 5 February 1996; accepted in revised form 24 September 1996)

\begin{abstract}
M. J. B. van den Hoff, R. H. Lekanne Deprez, M. Monteiro, P. A. J. de Boer, R. Charles and A. F. M. Moorman. Developmental Changes in Rat Cardiac DNA, RNA and Protein Tissue Base: Implications for the Interpretation of Changes in Gene Expression. Journal of Molecular and Cellular Cardiology (1997) 29, 629-639. During cardiac development the expression levels of many genes change as determined by Northern blot, dot blot, RNase protection, quantitative RT-PCR, Western blot or immunoprecipitation analyses. It is not always realized that the total amount of RNA or protein per gram of heart, dubbed tissue base, may change significantly during development as well. If this would be the case, this has to be taken into account. So far, the (changing) tissue base has not been established during cardiac development. To this end developmental profiles of cardiac DNA, RNA and protein concentration were determined in rats ranging in age from embryonic day 13 until neonatal day 121. The profiles show significant development changes in each parameter, that closely match the distinct growth phases of the developing heart and provide the parameters that are essential for an adequate interpretation of changes in the amount of a distinct mRNA and/or protein. In a comparison between in situ hybridization and Northern blot analysis it is demonstrated that the same developmental profile leads to an almost opposite conclusion depending on whether or not the changing tissue base is taken into account. These findings are of great interest for studies aimed at unravelling the molecular mechanisms underlying the regulation of gene expression during cardiac development.

(c) 1997 Academic Press Limited
\end{abstract}

KeY WorDs: Cardiac development; Protein content; RNA content; DNA content; Developmental profiles; Gene expression; In situ hybridization.

\section{Introduction}

Changes in gene expression during cardiac development are likely to reflect alterations in the function of the heart. About $90 \%$ of the volume of adult cardiac tissue comprises myocytes although they constitute less than one third of the total number of cells (Canale et al., 1986). During cardiac development three phases in growth of the myocytes can be identified (Zak, 1973; Rumyantsev, 1977; Bugaisky and Zak, 1979; Clubb and Bishop, 1984; Rakusan, 1984; Bishop, 1990, Claycomb, 1992). The first phase encompasses the entire embryonic and fetal period until birth proliferative (hyperplastic) growth of the myocytes is observed. In the second phase that lasts from birth till weaning,

Please address all correspondence to: Dr M. J. B. van den Hoff, Department of Anatomy and Embryology, University of Amsterdam, Academic Medical Center, Meibergdreef 15, 1105 AZ Amsterdam, The Netherlands. 
the labelling index of the myocytes gradually decreases (Clubb and Bishop, 1984) and concomitantly the myocytes become bigger (Bai et al., 1990). During this transition to hypertrophic growth more than $90 \%$ of rat cardiomycytes become binucleated as a result of karyokinesis without cytokinesis (Clubb and Bishop, 1984). In the third phase that lasts till death, the myocytes are in principle only able to grow by increasing their volume. Depending on the species, the age and/or the severity of pathology, an increase in ploidy and/ or number of myocytes is reported (Rumyantsev, 1977; Olivetti et al., 1987; Grajek et al., 1993; Kajustura et al., 1994; Quaini et al., 1994). In rat (Grove et al., 1969) and mouse (Soonpaa and Field, 1994) the restriction of DNA synthesis is almost complete in the third phase. In contrast to the myocytes, the non-muscle cells retain their capacity to proliferate during postnatal life; however, a concomitant decrease in their labelling index is observed, preventing a progressive heart weight due to non-muscle cell hyperplasia (Sasaki et al., 1970a; Clubb and Bishop, 1984).

It is to be expected that the different phases of cardiac growth are accompanied by changes in gene expression. Generally, the changes in amounts of a distinct messenger or protein in an organ are determined by semi-quantitave Northern, dot blot, RNAse protection, RT-PCR, immunoprecipitation or Western blot analyses in which the relative changes are expressed relative to the expression level of a housekeeping gene (e.g. glyceraldehyde 3-phosphate dehydrogenase), to the amount of total RNA (e.g. UV-measurement, ethidium bromide staining, $18 \mathrm{~S}$ or $28 \mathrm{~S}$ rRNA hybridization) or to the amount of total protein (biochemical determination). Because the growth characteristics of cardiac cells change during development, developmental changes in the references to be used may change as well.

To allow a proper appreciation of developmental changes of distinct mRNAs or proteins, we felt it necessary to know whether developmental changes in DNA, RNA and protein concentration occur during cardiac development. We now report the developmental profiles of rat cardiac DNA, RNA and protein concentration, providing a thorough reference for studies on gene expression during heart development. Using these data to correct the development profile of the sarcoplasmic reticulum $\mathrm{Ca}^{2+}$ ATPase mRNA allowed us to settle the apparent contradictory data from in situ and Northern blot hybridization analyses.

\section{Materials and Methods}

\section{Animals}

Wistar rats (Broekman, The Netherlands) were used and the day of coitus was set to zero. Normally, rats are born during the night of the 21 st and the morning of the 22 nd enbryonic day (ED). The day of birth was again set to zero to calculate the age of the newborn rats. Newborn rats are weaned at the 21st neonatal day (ND).

Until the day before birth (ED13-ED19) the hearts of fetuses of at least four litters were pooled per pregnant rat before analysis. From the day before birth (ED21) until the fourth day after birth (ND4) four litters per time point were analysed. The heart of each pup was assayed individually. After ND4, only male animals were included in this study to exclude interference due to sexual differences (Bai et al., 1990). Four rats were used per time point.

The heart and lungs were isolated en bloc and left beating in cold sterile physiological salt solution for $5 \mathrm{~min}$, to clean the heart of remaining blood, as blood cells contain DNA, RNA and protein, which is of particular importance in the perinatal period. This procedure does not lead to significant RNA degradation as assessed by Northern blot hybridization (data not shown). After removing the lungs, the major vessels and the pericardium, the wet weight of the heart was determined. The hearts of ED21 and postnatal rats were further dissected into atria and ventricles and again weighed. Tissue samples were snap frozen in liquid nitrogen and stored at $-80^{\circ} \mathrm{C}$ till further analysis.

\section{Determination of total protein, RNA and DNA}

Tissue samples were homogenized in 20 volume ice-cold sterile bi-distilled water using an ultraturrax homogenizer (Janke and Kunkerl; IKA Werken) and all subsequent steps were carried out on ice or at $4^{\circ} \mathrm{C}$ (Munro, 1966; Siddiq et al., 1993). In one tenth of the extract, total protein concentration (BCA-kit, Pierce) was determined. The remaining extract was divided into equal portions to determine RNA content using the orcinol assay (Munro, 1966) and DNA content using the diphenylamine assay (Burton, 1956). To determine cardiac RNA content the laborious orcinol assay was felt to be preferable to two-wavelength spectrophotometry methods, because in the latter tissue- 
specific extinction coefficients have to be used to calculate the RNA content. Based on data presented by Siddiq and coworkers (1993), it was anticipated that these extinction coefficients might differ during development, and would therefore have to be determined for each developmental stage separately.

The RNA concentration in the samples was determined by precipitation of the nucleic acids in $0.5 \mathrm{M} \mathrm{HClO}_{4}$, after which the RNA was hydrolysed by incubation in $0.3 \mathrm{M} \mathrm{KOH}$ at $60^{\circ} \mathrm{C}$ for $1 \mathrm{~h}$. After removal of DNA by $0.5 \mathrm{M} \mathrm{HClO}_{4}$ precipitation, the RNA concentration was determined by boiling the samples for $30 \mathrm{~min}$ in $6 \mathrm{M} \mathrm{HCl}, 0.01 \% \mathrm{FeCl}_{3}$ and $0.3 \%$ orcinol. Absorption was measured at $660 \mathrm{~nm}$. RNA concentrations were calculated using a calibration curve with highly purified total adult heart RNA that was isolated by ultracentrifugation through a caesium chloride cushion (Chirgwin et al., 1979) as a standard.

The DNA concentration in the samples was determined by hydrolysing the RNA in $0.1 \mathrm{~m} \mathrm{NaOH}$ after which the DNA was precipitated with half volume $10 \% \mathrm{HClO}_{4}$. The DNA was resuspended in $10 \%$ $\mathrm{HClO}_{4}$ and incubated at $70^{\circ} \mathrm{C}$ to hydrolyse the DNA. After clearing the solution by centrifugation, diphenylamine and acetaldehyde were added to a final concentration of $2 \%$ and $0.01 \%$, respectively. After an overnight incubation at $30^{\circ} \mathrm{C}$ the absorbance was determined at 560 and $700 \mathrm{~nm}$. The concentration in the samples was calculated relative to the included calibration curve that was prepared using highly purified herring testis DNA (Sambrook et al., 1989).

In additional control experiments we established that (1) the small amounts of residual DNA or RNA, that may contaminate the samples due to inadequate removal during sample preparation, did not influence the orcinol or diphenylamine assay, and that (2) recovery of DNA or RNA during extraction in sample preparation was almost complete as negligible quantities were found after re-extraction of the pellets. In addition, contaminating glycogen, which is expected to be present in reasonable amounts in developing rat heart (Houssaint et al., 1971; Tuganowski et al., 1975), was found to have no effect on the diphenylamine assay; it did influence the orcinol assay, albeit to an almost negligible extent, because even if the RNA preparation could be contaminated with an equal amount of glycogen it would result in less than $8 \%$ overestimation of the RNA content.

\section{Dot blot analysis}

SERCA2 mRNA concentration was determined by dot blot analysis. Approximately 2.5, 1.0 and
$0.25 \mu \mathrm{g}$ total ED21 and adult ventricular total RNA that was isolated by ultracentrifugation through a caesium chloride cushion (Chirgwin et al., 1979), was diluted in $50 \mu \mathrm{l}$ TE (TE: $10 \mathrm{~mm}$ Tris-HCl, $1 \mathrm{~mm}$ EDTA $\mathrm{pH}$ 8.0) for each sample. After addition of $30 \mu \mathrm{l} 20 \times$ SSC $(1 \times$ SSC: $150 \mathrm{~mm} \mathrm{NaCl}, 15 \mathrm{~mm} \mathrm{Na}-$ citrate $\mathrm{pH} 7.0$ ) and $20 \mu \mathrm{l} 37 \%$ formaldehyde, the samples were heated at $65^{\circ} \mathrm{C}$ for $15 \mathrm{~min}$ and quenched on ice. After addition of $300 \mu \mathrm{l}$ of icecold $10 \times \mathrm{SSC}$, the samples were spotted on prewetted Hybond $\mathrm{N}$ membranes (Amersham) using a dot blot manifold (Bio-Rad). After loading the samples, the slots were washed with $400 \mu \mathrm{l}$ $10 \times$ SSC. After air-drying and incubating the blots at $80^{\circ} \mathrm{C}$ for $1 \mathrm{~h}$, blots were hybridized in $0.5 \mathrm{M}$ sodium phosphate buffer $\mathrm{pH} 7.0\left(\mathrm{NaP}_{\mathrm{i}}\right) 7 \%$ SDS, $1 \mathrm{~mm}$ EDTA, 1\% BSA, $100 \mu \mathrm{g} / \mathrm{ml}$ heated-denatured herring testis DNA (Church and Gilbert, 1984). The SERCA2 mRNA was detected using an $\alpha^{32}$ P-labelled random-primed (Feinberg and Vogelstein, 1984) probe of the $1.7 \mathrm{~kb} 3^{\prime}$ end of rat sarcoplasmic reticulum $\mathrm{Ca}^{2+}$-ATPase (Moorman et al., 1995) and $18 \mathrm{~S}$ ribosomal RNA was detected using an $\alpha^{32} \mathrm{P}-$ tailed oligonucleotide probe (Mendez et al., 1987). After overnight hybridization of the blots at $65^{\circ} \mathrm{C}$ for the SERCA2 probe and at $42^{\circ} \mathrm{C}$ for the $18 \mathrm{~S}$ probe, they were washed in sequential dilution of $\mathrm{NaP}_{\mathrm{i}}$, with a final wash in $15 \mathrm{~mm} \mathrm{NaP}, 1 \%$ SDS for $15 \mathrm{~min}$ at $60^{\circ} \mathrm{C}$ for the SERCA2 probe and $35^{\circ} \mathrm{C}$ for the oligonucleotide probe. Hybridization signals were quantified using PhosphorImager ${ }^{\mathrm{TM}}$ (Molecular Dynamics).

\section{In situ hybridization}

ED21 heart-lung preparations were fixed for $4 \mathrm{~h}$ at room temperature and adult hearts were fixed overnight at $4^{\circ} \mathrm{C}$ in $4 \%$ paraformaldehyde dissolved in PBS and embedded in paraplast. Seven $\mu \mathrm{m}$ sections were pretreated and hybridized to an $\alpha^{32} S-$ labelled cRNA probe of the $1.7 \mathrm{~kb} 3^{\prime}$ end of rat sarcoplasmic reticulum $\mathrm{Ca}^{2+}$-ATPase as described (Moorman et al., 1993 and 1995). A calibration curve was prepared by mixing different amounts of radioactivity in gelatin drops, applied on object glasses (Fig. 3C). After exposure and development of the autoradiographic emulsion, the optical density (OD) of the hybridization signal was measured in the ventricles, fibrous tissue of the valves, in the arterial pole, and in the calibration spots. Densities measured were converted into radioactivity per $\mathrm{mm}^{2}$ using the calibration curve (Fig. 3D). Density in fibrous tissue (valves and arterial pole) was 
Table 1 Developmental profile of the wet weight, protein, RNA and DNA concentration of the rat heart

\begin{tabular}{lcccc}
\hline Age & $\begin{array}{c}\text { Wet weight } \\
(\mathrm{mg})\end{array}$ & $\begin{array}{c}\text { Protein } \\
(\mu \mathrm{g} / \mathrm{mg})\end{array}$ & $\begin{array}{c}\text { RNA } \\
(\mu \mathrm{g} / \mathrm{mg})\end{array}$ & $\begin{array}{c}\text { DNA } \\
(\mu \mathrm{g} / \mathrm{mg})\end{array}$ \\
\hline ED13 & $0.8 \pm 0.1$ & $54.8 \pm 6.3$ & $4.5 \pm 0.3$ & $11.2 \pm 0.4$ \\
ED14 & $1.3 \pm 0.1$ & $57.0 \pm 3.8$ & nd & $5.3 \pm 0.1$ \\
ED15 & $2.6 \pm 0.0$ & $51.0 \pm 0.5$ & $4.2 \pm 0.3$ & $6.1 \pm 0.1$ \\
ED16 & $3.2 \pm 0.3$ & $58.8 \pm 4.4$ & nd & $6.7 \pm 0.6$ \\
ED17 & $4.4 \pm 0.1$ & $72.7 \pm 4.9$ & $6.2 \pm 0.4$ & $7.2 \pm 0.4$ \\
ED18 & $8.6 \pm 0.1$ & $57.8 \pm 3.2$ & $5.5 \pm 0.3$ & $5.9 \pm 0.2$ \\
ED19 & $12.5 \pm 0.5$ & $57.8 \pm 2.9$ & $5.5 \pm 0.3$ & $4.8 \pm 0.1$ \\
ED21 & $28.0 \pm 0.1$ & $72.5 \pm 2.6$ & $4.8 \pm 0.1$ & $6.3 \pm 0.1$ \\
ND0 & $29.3 \pm 1.8$ & $91.0 \pm 3.9$ & $5.8 \pm 0.2$ & $7.7 \pm 0.5$ \\
ND1 & $35.6 \pm 0.6$ & $82.3 \pm 7.8$ & $6.2 \pm 0.1$ & $6.9 \pm 0.1$ \\
ND4 & $68.1 \pm 1.7$ & $75.0 \pm 5.4$ & $5.9 \pm 0.1$ & $7.1 \pm 0.2$ \\
ND7 & $94.7 \pm 11.9$ & $67.9 \pm 14.2$ & $5.2 \pm 0.2$ & $9.5 \pm 0.2$ \\
ND16 & $160.7 \pm 8.7$ & $121.6 \pm 6.4$ & $4.1 \pm 0.1$ & $8.1 \pm 0.4$ \\
ND20 & $272.3 \pm 10.7$ & $188.8 \pm 10.8$ & $3.2 \pm 0.4$ & $7.8 \pm 1.0$ \\
ND31 & $423.3 \pm 49.6$ & $125.1 \pm 16.5$ & $2.3 \pm 0.2$ & $6.0 \pm 0.5$ \\
ND39 & $611.0 \pm 38.3$ & $139.0 \pm 8.9$ & $2.2 \pm 0.2$ & $6.1 \pm 1.2$ \\
ND45 & $646.1 \pm 27.6$ & $116.3 \pm 20.2$ & $1.9 \pm 0.1$ & $5.6 \pm 0.5$ \\
ND53 & $868.5 \pm 39.8$ & $161.7 \pm 11.1$ & $1.9 \pm 0.3$ & $5.4 \pm 1.3$ \\
ND77 & $1106.5 \pm 34.6$ & $133.9 \pm 1.7$ & $2.1 \pm 0.2$ & $4.7 \pm 0.2$ \\
ND121 & $1217.8 \pm 30.6$ & $152.0 \pm 9.5$ & $1.4 \pm 0.1$ & $4.7 \pm 0.2$ \\
\hline
\end{tabular}

The presented data are the means and standard deviations of at least four independent determinations. The entire hearts of rats of the ages ranging from ED13 to ED19 were pooled per litter before analysis. The entire hearts of rats beyond ED19 were assayed individually. For the age range ED21 to ND4 all litter mates of four different litters were assayed and for ages from ND7 onward the hearts of four male rats were analysed. $n d$ : not determined.

considered to be tissue background and was subtracted. The values given are the means of four closely adjacent sections. The recordings were made using a cooled CCD camera with a KAF chip (Photometrics, Tucson, AZ, USA). The image processing package SCIL-image (Technical University, Delft, The Netherlands) was used to convert the stored grey value images to transmission images and subsequently to density images. Densities were determined using a Macintosh II computer and the public domain program NIH-image (written by Wayne Rasband at the US National Institutes of Health and available electronically via internet by anonymous ftp from zippy.nimh.nih.gov.). The relationships between optical densities, exposure, development of the autoradiographic emulsion and the radioactivity present in the sections is discussed extensively elsewhere (Jonker et al., 1996).

\section{Results}

Table 1 shows the wet weight and the protein, RNA and DNA concentrations of the entire heart, including both atria and ventricles. The calculated standard deviations are small, indicating (1) the high reproducibility of the isolation procedure and biochemical determinations and (2) the relatively small biological variation between different litters. The reliability is further underscored by the fact that the adult values obtained in this study are similar with those reported in literature (Sasaki et al., 1968; Siddiq et al., 1993). Furthermore, the obtained standard deviations are comparable to the ones obtained when hearts of individual fetuses were assayed (data not shown).

The wet weight of the heart increases 35-fold between ED13 and the day before birth (ED21), 10fold in the suckling period (NDO-ND20), and 4-fold after weaning till ND121. When the age of the animal is plotted against the wet weight of the heart, the wet weight increases exponentially until the day before birth (ED21) [Fig. 1(a)]. After a transient growth arrest in the perinatal period (ED21-ND1) the wet weight starts to increase again. The increase in wet weight is no longer exponential but linear [Fig. 1(b)]. This linear increase can be divided into two portions: (1) a rather steep increase until ND53 (15.8 mg/day) and (2) a shallow increase from ND53 till ND121 (4.8 mg/ day). The development profiles of total protein, RNA and DNA content in the entire heart, which is obtained by multiplying the wet weight by the protein, RNA or DNA concentration indicated in Table 1, closely resemble the shape of the profile of 


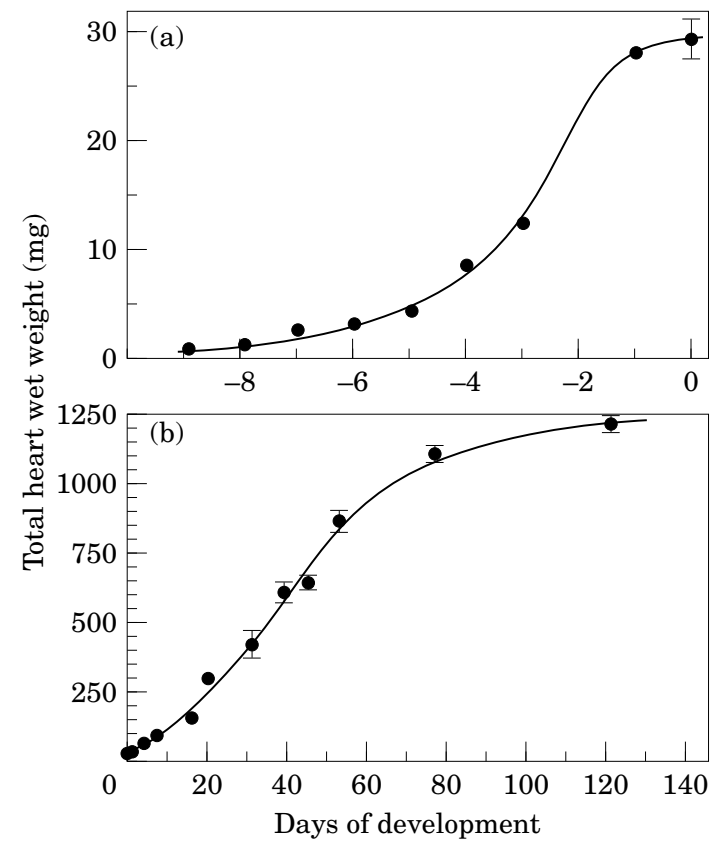

Figure 1 Developmental changes in cardiac wet weight. Developmental profiles of wet weight of the rat heart, including atria and ventricles, are shown for the prenatal (a) and postnatal (b) period. Each time point before birth represents the average of at least four different litters, in which the fetal hearts were pooled before analysis. Each time point up to 4 neonatal days represents the average values of individual hearts isolated from at least 4 different litters and for each time point beyond four neonatal days the hearts of four male rats were assayed separately. The error bars indicate the standard deviation (see Table 1). In some points the standard deviation is not visible in this representation, because they are so small that they are included in the marker

the wet weight, and also show an exponential increase before birth and a linear increase after birth (graphs not shown).

To allow easy identification of developmental changes in the protein, RNA and DNA concentrations in the heart, the data of ED13 till ND31 are presented in graphs [Fig. 2(a-c)]. Ages beyond ND31 are not included in these graphs because their levels do not change considerably (Table 1). The protein concentration [Fig. 2(a)] is fairly constant in the embryonic and fetal period, after which it starts to increase and reaches its almost 3-fold higher adult level at weaning. The RNA concentration [Fig. 2(b)] increases 1.5-fold in the prenatal period to reach its maximal value in the perinatal period, after which it decreases almost 3fold to reach its adult level. The DNA concentration [Fig. 2(c)] gradually increases almost 2-fold to reach a maximum in the suckling period and decreases almost 2-fold to reach its adult level. The DNA concentrations after birth are in agreement with previously presented data by Sasaki et al. (1968). Between ED13 and ED14 a more than 2-fold decrease in the DNA concentration is observed [Fig. 2(c)] which is not in line with the indicated trendline. Initial impressions would appear to indicate that the sharp drop in the DNA concentration is an artifact due to an error in the determination of the wet weight or due to the necessarily small sample size used in the biochemical determinations. An erroneous determination of the wet weight is unlikely because the protein and RNA concentrations [Fig. 2(a,b)], which are determined in parallel experiments of the same extracts, are in line with the next points in development. Secondly, the biochemical determination is sufficiently sensitive because when references ranging from $2 \mu \mathrm{g} /$ $\mathrm{ml}$ to $160 \mu \mathrm{g} / \mathrm{ml}$ DNA were included in the diphenylamine assay a linear relation was obtained with an $r$-value of at least 0.997 , thus, theoretically, allowing determination of the DNA content of an individual ED13 heart.

From the data presented in Table 1 the protein per RNA, the protein per DNA and the RNA per DNA ratios were calculated by dividing the appropriate values. The graph of the protein per RNA ratio [Fig. 2(d)] shows that this ratio is constant up to ND7 after which it increases 6-fold to reach its adult level at weaning. The graph of the protein per DNA ratio [Fig. 2(e)] shows a gradual prenatal increase of almost 1.5-fold and a fairly constant ratio in the perinatal period and the first week after birth, after which the ratio increases again 2 -fold to reach its adult level at weaning. The graph of the RNA per DNA ratio [Fig. 2(f)] shows a maximum at ED19, that is reached by a 3 -fold increase in the embryonic and fetal period and a 3-fold decrease in the perinatal and suckling period.

From hearts of rats ranging in age from ED21 to ND121 ventricles and atria were isolated separately. Table 2 shows the average values of the determined wet weight, and protein, RNA and DNA concentrations.

The wet weight of the ventricles increases during the entire range of ages assayed; it remains fairly constant in the perinatal period displaying a relative constant increase until ND53 (14.5 mg/day) after which the rate of increase decreases about 3-fold. The protein concentration of the ventricle remains almost constant in the perinatal period and the first 2 weeks after birth and between ND31 and ND121. The relative low neonatal level shifts to the relative high adult level in the second and third postnatal weeks. The RNA concentration is, on average, constant in the ventricles in the perinatal period and the first week after birth, after which it gradually 

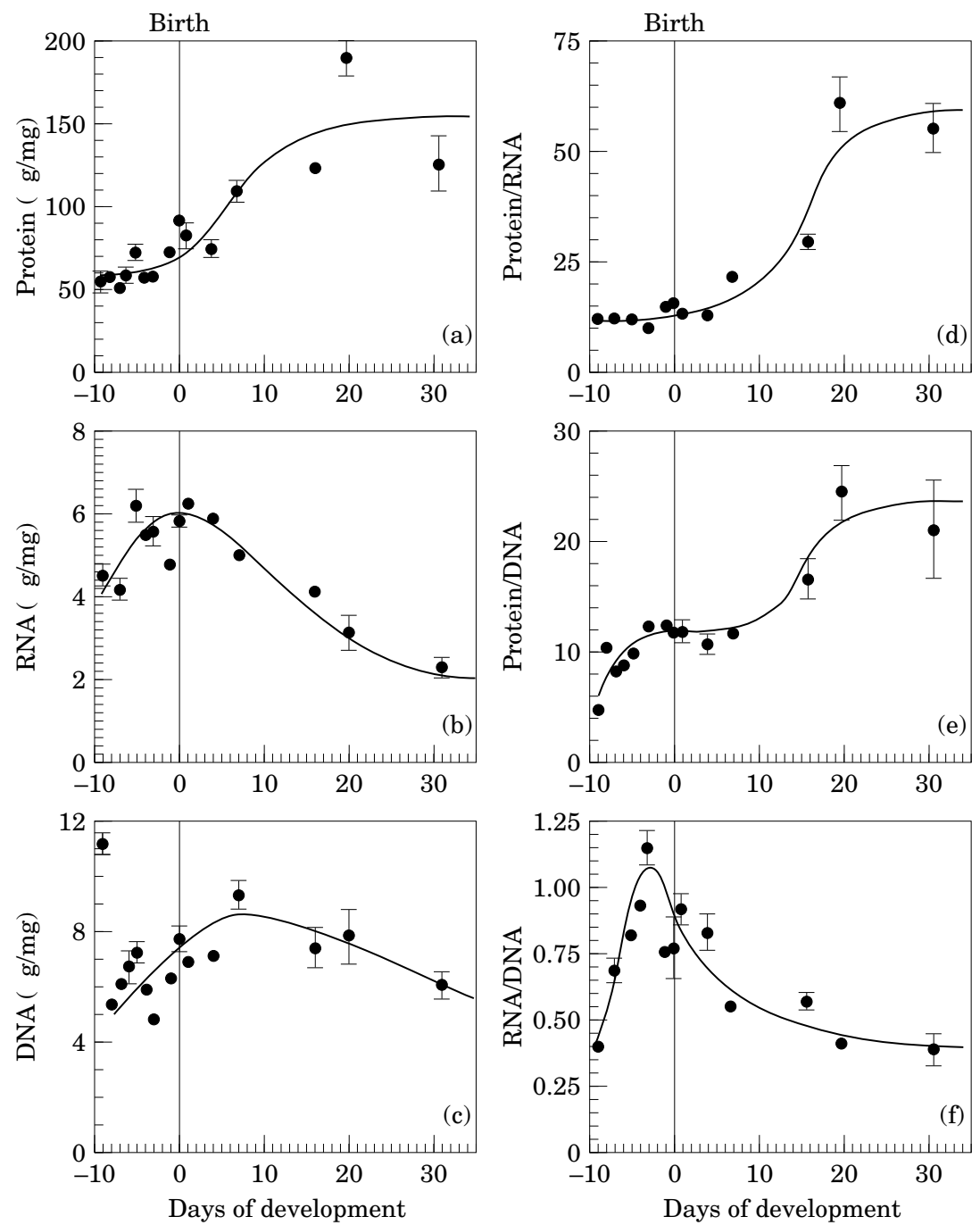

Figure 2 Developmental profiles of the cardiac protein, RNA and DNA concentration. Developmental profiles of the entire rat heart are shown from 10 days before birth until 31 days after birth. Going from top to bottom in the left column the protein concentration (a), total RNA concentration (b) and DNA concentration (c) are shown. In the right column going from top to bottom the ratios protein per RNA (d), protein per DNA (e) and RNA per DNA (f) are shown. Each time point before birth represents the average of at least four different litters, in which the fetal hearts were pooled before analysis. Each time point up to 4 neonatal days represents the average values of individual hearts isolated from at least four different litters and for each time point beyond 4 neonatal days the hearts of four male rats were assayed separately. The error bars indicate the standard deviation (see Table 1). In some points the standard deviation is not visible in this representation, because they are so small that they are included in the marker.

decreases during subsequent development to become more than 4-fold lower at ND121 compared to ND0 and ND1. The DNA concentration of the ventricles is, on average, constant during the perinatal and suckling period, after which it decreases gradually with age.

The wet weight of the atria increases during the entire range of ages assayed; it remains fairly constant in the perinatal period, displaying a relative constant increase until ND53 (atria $1.4 \mathrm{mg}$ / day) after which it decreases about 3-fold. Due to these comparable growth profiles of ventricles and atria, the relative contribution of the wet weight of the atria to the entire heart remains about one eighth of the total heart wet weight $(12.4 \% \pm 3.1 \%)$. We did not determine the prenatal values because the size of the samples does not allow reliable determinations of wet weight, protein, RNA and DNA. The protein concentration of the atria increases sharply immediately after the perinatal period to reach a maximum between ND4 and ND7, after which it gradually decreases to its adult level. The RNA concentration of the atria is, on average, constant in the perinatal period and the first week 
Table 2 Developmental profile of wet weight, and protein, RNA and DNA concentration of ventricles and atria of rat heart

\begin{tabular}{|c|c|c|c|c|c|c|c|c|}
\hline \multirow[b]{2}{*}{ Age } & \multicolumn{4}{|c|}{ Ventricles } & \multicolumn{4}{|c|}{ Atria } \\
\hline & $\begin{array}{l}\text { Wet weight } \\
(\mathrm{mg})\end{array}$ & $\begin{array}{l}\text { Protein } \\
(\mu \mathrm{g} / \mathrm{mg})\end{array}$ & $\begin{array}{c}\text { RNA } \\
(\mu \mathrm{g} / \mathrm{mg})\end{array}$ & $\begin{array}{c}\text { DNA } \\
(\mu \mathrm{g} / \mathrm{mg})\end{array}$ & $\begin{array}{l}\text { Wet weight } \\
\quad(\mathrm{mg})\end{array}$ & $\begin{array}{l}\text { Protein } \\
(\mu \mathrm{g} / \mathrm{mg})\end{array}$ & $\begin{array}{c}\mathrm{RNA} \\
(\mu \mathrm{g} / \mathrm{mg})\end{array}$ & $\begin{array}{c}\text { DNA } \\
(\mu \mathrm{g} / \mathrm{mg})\end{array}$ \\
\hline ED21 & $22.7 \pm 0.5$ & $80.4 \pm 3.5$ & $4.9 \pm 0.1$ & $6.4 \pm 0.2$ & $4.6 \pm 0.2$ & $55.8 \pm 1.9$ & $4.1 \pm 0.2$ & $4.9 \pm 0.2$ \\
\hline NDO & $24.0 \pm 1.8$ & $97.0 \pm 5.3$ & $6.3 \pm 0.2$ & $8.1 \pm 0.5$ & $5.3 \pm 0.1$ & $64.2 \pm 1.6$ & $3.6 \pm 0.2$ & $6.1 \pm 0.5$ \\
\hline ND1 & $30.2 \pm 0.6$ & $87.8 \pm 9.0$ & $6.5 \pm 0.1$ & $7.1 \pm 0.1$ & $5.4 \pm 0.2$ & $53.3 \pm 9.8$ & $5.0 \pm 0.2$ & $5.5 \pm 0.2$ \\
\hline ND4 & $59.8 \pm 1.6$ & $57.5 \pm 6.7$ & $5.9 \pm 1.6$ & $7.2 \pm 0.2$ & $8.3 \pm 0.3$ & $198.8 \pm 34.2$ & $5.3 \pm 0.2$ & $6.4 \pm 0.2$ \\
\hline ND7 & $83.9 \pm 10.7$ & $59.4 \pm 14.7$ & $5.2 \pm 0.2$ & $9.9 \pm 0.2$ & $10.8 \pm 1.5$ & $142.3 \pm 28.2$ & $4.7 \pm 0.3$ & $6.8 \pm 0.5$ \\
\hline ND16 & $147.0 \pm 8.1$ & $118.1 \pm 6.2$ & $4.1 \pm 0.1$ & $8.0 \pm 0.5$ & $13.7 \pm 0.6$ & $158.4 \pm 19.1$ & $4.3 \pm 0.3$ & $9.0 \pm 0.4$ \\
\hline ND20 & $236.9 \pm 9.8$ & $196.8 \pm 9.3$ & $3.2 \pm 0.4$ & $7.9 \pm 0.9$ & $35.4 \pm 3.1$ & $128.3 \pm 27.7$ & $3.0 \pm 0.9$ & $6.8 \pm 1.3$ \\
\hline ND31 & $374.0 \pm 52.6$ & $125.8 \pm 18.3$ & $2.3 \pm 0.3$ & $6.1 \pm 0.4$ & $49.3 \pm 19.6$ & $120.1 \pm 16.8$ & $1.9 \pm 0.1$ & $6.0 \pm 0.6$ \\
\hline ND39 & $551.7 \pm 36.7$ & $139.3 \pm 8.9$ & $2.2 \pm 0.1$ & $6.1 \pm 1.3$ & $59.3 \pm 3.8$ & $119.9 \pm 13.3$ & $2.7 \pm 0.6$ & $6.2 \pm 1.6$ \\
\hline ND45 & $580.2 \pm 36.3$ & $118.4 \pm 23.5$ & $1.8 \pm 0.1$ & $5.5 \pm 0.7$ & $65.9 \pm 14.2$ & $130.5 \pm 13.3$ & $2.4 \pm 0.3$ & $6.3 \pm 1.6$ \\
\hline ND53 & $796.2 \pm 27.1$ & $161.1 \pm 12.8$ & $1.9 \pm 0.3$ & $5.5 \pm 1.2$ & $72.3 \pm 17.0$ & $118.4 \pm 34.6$ & $2.2 \pm 0.4$ & $5.4 \pm 1.6$ \\
\hline ND77 & $926.5 \pm 16.3$ & $130.2 \pm 12.9$ & $1.7 \pm 0.3$ & $5.1 \pm 0.6$ & $180.0 \pm 50.9$ & $89.1 \pm 19.3$ & $2.2 \pm 0.1$ & $4.8 \pm 0.3$ \\
\hline ND121 & $1107.4 \pm 3.2$ & $156.3 \pm 12.5$ & $1.4 \pm 0.1$ & $3.8 \pm 0.2$ & $110.4 \pm 27.4$ & $111.0 \pm 11.0$ & $1.6 \pm 0.1$ & $4.7 \pm 0.1$ \\
\hline
\end{tabular}

The presented data are the means and standard deviations of at least four independent determinations. The atria and ventricles were each analysed separately. For the age range ED21 to ND4 all litter mates of four different litters were assayed and for ages from ND7 onward four male rates were analysed.

after birth, after which it gradually decreases during subsequent development to become more than 4fold lower at ND121 compared to ND0 and ND1. The profile of the RNA concentration of the atria is comparable to that of the ventricles. The DNA concentration of the atria is on average constant during the perinatal and suckling period, though the DNA concentration of the atria is almost one fifth lower than in ventricles in this period. After weaning, the DNA concentration of the atria decreases gradually with age, in a comparable way to that observed in the ventricles.

\section{Discussion}

\section{Developmental profiles}

In the adult heart about $90 \%$ of the volume of the cardiac tissue comprises myocytes, but they appear to constitute less than $30 \%$ of the total number of cells. The other $70 \%$ are non-muscle cells of which the majority are fibroblasts and capillary cells (Canale et al., 1986). The growth characteristics of myocytes, fibroblasts and endothelial cells were found to differ considerably during postnatal life (Sasaki et al., 1970a; Clubb and Bishop, 1984; Rakusan, 1984; Rakusan and Turek, 1985; Gerdes et al., 1986; Bai et al., 1990), suggesting that the relative contribution of each cell type changes during cardiac development, complicating the interpretation of the developmental profiles presented in this study. Initial inspection of the data shows that the graphs (Fig. 2) can roughly be divided into three phases: two relatively constant phases, the prenatal period and the period after weaning, and in between, the perinatal and suckling period, showing relatively large changes. Because myocyte growth during cardiac development displays a prenatal hyperplastic phase, a transitional period during the late fetal and first three postnatal weeks, and a hypertrophic 'adult' period (Zak, 1973; Rumyantsev, 1977; Bugaiski and Zak, 1979; Clubb and Bishop, 1984; Rakusan, 1984; Bishop, 1990; Claycomb, 1992), these observations may suggest that the observed changes are accounted for to a large extent by the myocytes, although changes in the other cardiac cell types can not be ruled out. This holds particularly for the changes in DNA concentration during development. The proliferative or biosynthetic phase is characterized by relative high RNA and DNA concentrations and relative low protein concentration (Table 1, Fig. 2), whereas the hypertrophic or bioactive phase, i.e. the mature heart, is characterized by low RNA and DNA concentrations and a high protein concentration (Table 1, Fig. 2).

In the fetal and embryonic period the number of myocytes increases due to proliferative growth (Rumyantsev, 1964); this correlates with the exponential increase in the DNA content, which is obtained by multiplying the wet weight by the DNA concentration indicated in Table 1 , in the entire heart in this period. The linear increase in the DNA content of the heart in the suckling period correlates with the observations that (1) the labelling index 
of myocytes was found to decrease and (2) although fibroblasts retain their capacity to proliferate during postnatal life, their labelling index also decreases in parallel to the decrease observed in myocytes (Sasaki et al., 1970; Clubb and Bishop, 1984). Interestingly, the increase in the DNA content per heart does not stop at the end of the suckling period but lasts until about 2 months. This increase in DNA content per heart indicates that either a specific population of cells is actively dividing or that all cells are undergoing one or some very slow final rounds of cell division. The latter explanation is most likely because Clubb and Bishop (1984) showed about $1 \%$ labelling of the myocytes and $4 \%$ of the non-muscle cells and Sasaki et al. (1970a) showed about $0.2 \%$ and $1 \%$ respectively, using $\left[{ }^{3} \mathrm{H}\right]$ thymidine pulse-labelling of weanlings. The observed decrease in the DNA concentration and the increase in the protein concentration fits the observations that (1) the myocytes were found to increase their cell volume by hypertrophic growth, and (2) the majority of the myocytes became binucleated (Clubb and Bishop, 1984; Gerdes et al., 1986; Bai et al., 1990). The transient increase in DNA concentration in the first weeks after birth might be explained by the observation that about half of the adult capillaries in the mammalian heart are thought to be formed in this period (Rakusan, 1984; Rakusan and Turek, 1985).

Interestingly, the RNA concentration decreases almost 4-fold in ventricles and about 3-fold in the atria between the suckling period and adolescence (Table 2), whereas the protein per RNA ratio increases more than 10-fold in the ventricles and almost 5-fold in the atria (calculated from the data in Table 2). The change in this ratio may be due to (1) more efficient translation of mRNA, (2) changes in the ratio mRNA per total RNA, or (3) to an increase in the half-life of proteins in developing myocytes. All three options are probably involved in the observed developmental changes. Available evidence obtained in pressure overload induced hypertrophy indicates that the content of functional ribosomes per cell is elevated (Hannan and Rothblum, 1995), resulting in a more efficient translation of mRNA. The ratio polyA ${ }^{+}$RNA per $18 \mathrm{~S}$ ribosomal RNA was observed to increase almost 2-fold in the third postnatal week (Farhadian et al., 1994). Thirdly, the myocytes become functionally mature in this period, i.e. the myocytes stop dividing, the intercalated disks are formed and the myofibrilar structures become highly organized (Bugaisky and Zak, 1979), suggesting an increase in the half-life of protein involved. The RNA con- centration and the ratio protein per RNA are both higher in atria than in ventricles (Table 2) which might be imposed by the changed cardiovascular physiological requirements and the differences in the state of maturation of atrial and ventricular myocytes (Canale et al., 1986; Rumyantsev, 1977; Bishop, 1990; Schwartz et al., 1993; Rockman et al., 1994).

\section{Waves of cell division?}

Although on average DNA concentration increases before birth, an oscillation can be observed with a maximum at ED17 and one in the perinatal period [Fig. 2(c)]. The fact that this plot was obtained using hearts of fetuses isolated from four different pregnant rats underscores the significance of the observed phenomenon. Such an oscillation in the DNA concentration could be explained if waves of cell divisions were occurring in the developing heart (Stalsberg, 1969; Thompson et al., 1990, 1995). If one compares the DNA content per heart at ED14 $(6.9 \mu \mathrm{g}$; calculated from Table 1$)$ and the day of birth $(225.6 \mu \mathrm{g}$; calculated from Table 1$)$ and one assumes that all cells are equally active dividing, then at least five rounds of cell division must have occurred and the generation time would be $38 \mathrm{~h}$. Thus, the observed maximum in DNA concentration at ED17 and in the perinatal period does not fit with the notion of synchronously dividing hearts cells, because every $38 \mathrm{~h}$ a maximum would be expected. A bromodeoxyuridine (BrdU) pulse resulted in labelling of about $40 \%$ of the nuclei in ED14 ventricles and of $15 \%$ in ED21 ventricles (unpublished observations). From these data one can calculate that the average generation time of the ventricular cells is $17-22 \mathrm{~h}$ at ED14 and $47-60 \mathrm{~h}$ at ED21, assuming that (1) the DNA synthetic time is 7-9 h (Rumyantsev, 1964), (2) all cell types are equally active dividing and (3) BrdU staining represents cells in S-phase. These estimated generation times of ventricular cells during development are in agreement with previously reported observations (Rumyantsev, 1964; Sasaki et al., 1970b).

\section{Implications of changes in tissue base}

The level of expression of many distinct mRNAs and proteins have been established during development and/or in experimental models. Often the implicit but, as shown in this study, erroneous assumption has been made that total RNA and/or protein 
Table 3 Relative expression levels of sarcoplasmic reticulum $\mathrm{Ca}^{2+}$ ATPase mRNA in rat ventricles

\begin{tabular}{lrrc}
\hline & Fetus & Adult & $\begin{array}{c}\text { Ratio adult } \\
\text { to fetus }\end{array}$ \\
\hline $\begin{array}{l}\text { Northern blot (Lompré } \text { et al., } \\
\quad 3991)\end{array}$ & $37 \%$ & $85 \%$ & 2.3 \\
$\begin{array}{l}\text { Dot blot (this study) } \\
\text { Total RNA per wet weight }\end{array} \quad 100 \%$ & $223 \%$ & 2.2 \\
$\quad$ Corrected Northern blot & $100 \%$ & $29 \%$ & 0.3 \\
$\quad$ Corrected Dot blot & $100 \%$ & $67 \%$ & 0.7 \\
In situ hybridization & $100 \%$ & $67 \%$ & 0.7 \\
\hline
\end{tabular}

The in situ hybridization signals were obtained by hybridizing a cRNA probe to SERCA2 mRNA to a heart-lung preparation of an ED21 rat fetus and to an adult rat heart (ND121). The hybridization signal is measured as optical densities. Radioactivity was calculated using a reference curve. The signal of ED21 (see Fig. 3) was set to $100 \%$. The Northern blot data are taken from Lompré et al, (1991) and shown as SERCA2 mRBA levels corrected for $18 \mathrm{~S}$ ribosomal RNA hybridization. In their analysis the level found in ND4 rat ventricles was set to $100 \%$. The dot blot data (blots not shown) were obtained by hybridizing the SERCA2 probe to about $2.5 \mu \mathrm{g}, 1.0 \mu \mathrm{g}$ and $0.5 \mu \mathrm{g}$ total RNA isolated from ED21 and adult ventricles. The values shown are obtained after correcting the SERCA2 mRNA levels for $18 \mathrm{~S}$ ribosomal RNA hybridization and setting the level in ED21 ventricles to $100 \%$. Total RNA per wet weight is taken from Table 2 and the value found in ED21 ventricles was set at $100 \%$. The 'corrected' values, which show specific SERCA2 mRNA per wet weight were obtained by multiplying the data obtained for Northern blot or dot blot (specific mRNA/total RNA) by total RNA per wet weight. The value of ED21 was again set at $100 \%$.

concentration of a tissue or organ, dubbed the tissue base, does not change during development or due to the experimental condition. To illustrate a possible implication of the developmental change in tissue base on the interpretation of Northern blot data, we have compared a well-documented Northern blot study on sarcoplasmic reticulum $\mathrm{Ca}^{2+}$-ATPase mRNA encoded by the SERCA2 gene, with in situ hybridization analysis. Northern blot analysis had shown that mRNA levels of SERCA2 increase 2.3fold when total RNA is isolated from ED19 and adult ventricles (Lompré et al., 1991) (see Table 3). At first glance these data suggest a developmental increase. However, if one takes into account that before birth the total RNA concentration is 3-fold higher than after birth, the corrected figure obtained in this way shows a developmental decrease. This figure is more in agreement with the impression from in situ hybridization to a SERCA2 probe in sections of fetal and adult hearts (Fig. 3; see also e.g. Moorman et al., 1995). To allow a comparison of the Northern blot and/or dot blot data with the in situ hybridization data, we have quantified the density of silver grains due to specific hybridization per unit area. Within limits, the density of the silver grains is proportional to the amount of radioactivity per $\mathrm{mm}^{2}$ as shown in Figures $3 \mathrm{C}$ and D. In the adult ventricle (Fig. 3A) the radioactivity per $\mathrm{mm}^{2}$ due to SERCA2 mRNA hybridization was found to be about one third lower than in the fetal ventricle
(Fig. 3B). This figure (0.6) is comparable with the corrected Northern blot and corrected dot blot data (0.7) (Table 3). Formally, the densities of all sections of the entire ventricles should be measured, but as no significant heterogeneity was observed of SERCA2 mRNA expression in the ventricles, we have limited the measurements to four closely adjacent sections. Thus, if corrected Northern blot and/or dot blot data are comparable with in situ hybridization data. We note also that the data collected in this study allow one to assess whether developmental changes in the ratio of the level of a specific protein to specific mRNA occurs: (specific protein/total protein $) \times($ total protein $/$ total RNA $) \times($ total RNA $/$ specific $\mathrm{mRNA})=($ specific protein/specific mRNA).

\section{General conclusion}

In summary, the developmental profiles presented in this study show that cardiac protein concentration increases almost 3-fold, RNA concentration decreases almost 4-fold and DNA concentration decreases almost 2-fold in the first postnatal weeks. For an adequate interpretation of the changes in the amounts of a distinct mRNA or protein measured at different developmental stages these changes in tissue base should be taken into account. Such considerations may be helpful in the understanding 

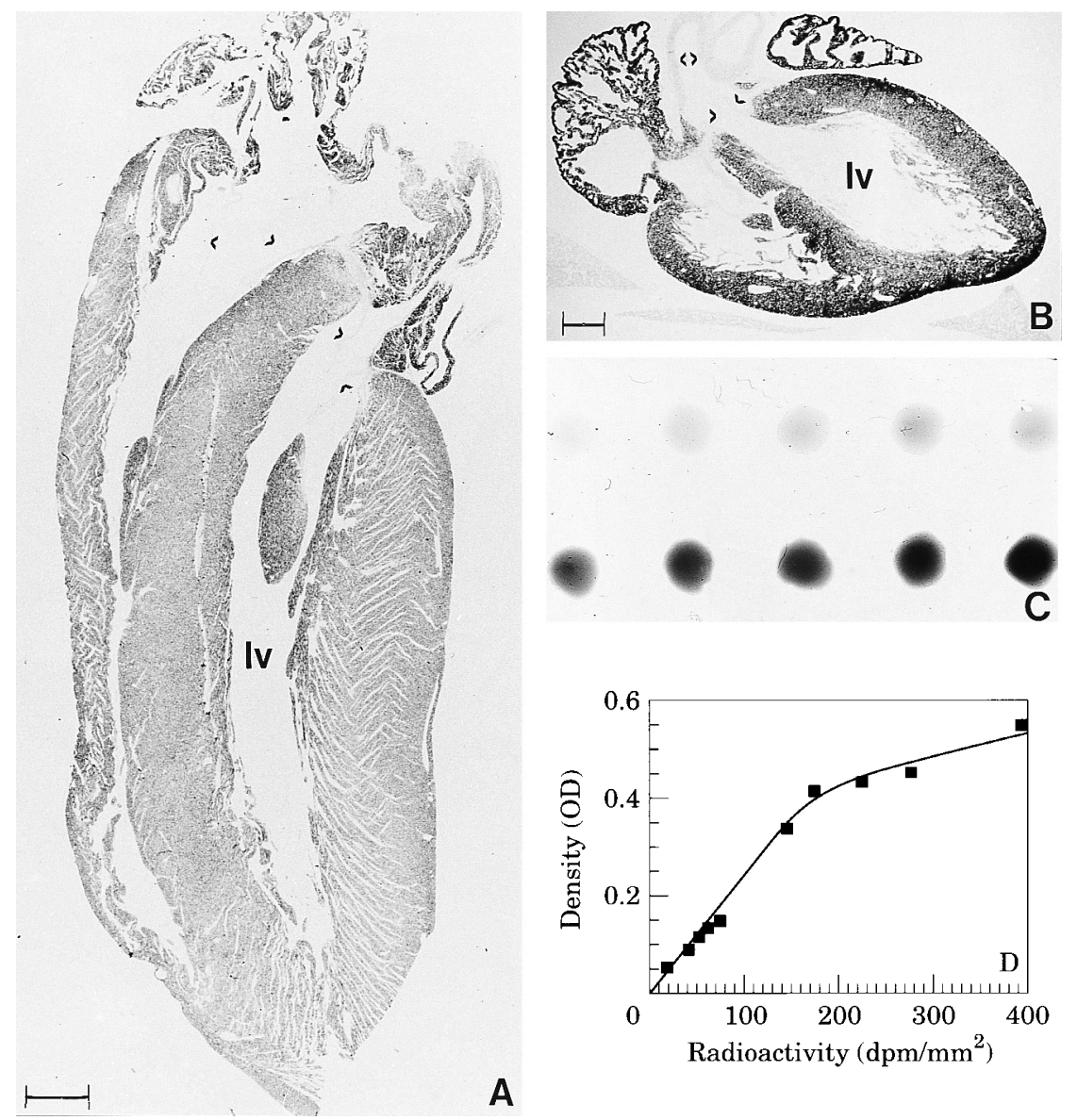

Figure 3 In situ hybridization of SERCA2 mRNA. In situ hybridization analysis was performed on sections from an adult (ND121) heart A and on an ED21 rat heart B using a $\left.{ }^{35} \mathrm{~S}\right]$-labelled cRNA probe to sarcoplasmic reticulum $\mathrm{Ca}^{2+}$ ATPase (SERCA2) mRNA. In the same experiment a microscope slide, on which gelatin drops were applied with known amounts of radioactivity, was included to make a calibration curve $\mathrm{C}$. This slide was processed in the same way as the sections. Optical densities were measured in each calibration spot and plotted against the amount of dpm/ $/ \mathrm{mm}^{2}$ in each calibration spot D. The density of the ventricles was measured and the amount of radioactivity was calculated from the calibration curve, after subtraction of the tissue background (density determined in the fibrous tissue of the valves and arterial pole (arrow heads)). In the fetal and adult ventricle the amount of radioactivity was found to be 136 and $84 \mathrm{dpm} / \mathrm{mm}^{2}$, respectively. The variation in different measurements was less than $10 \%$. The bars represent $1 \mathrm{~mm}$ in panel A and B. The left ventricle is indicated as lv.

of the molecular mechanism underlying their expression. Furthermore, we have shown that the changing tissue base is one of the causes, if not the primary, underlying the interpretational variances between in situ and Northern hybridization analysis. Ideally, one would like to investigate the changes of a distinct mRNA or protein in only those cells of a tissue or organ that expresses the mRNA or protein. To realize this goal one should perform quantitative in situ hybridization and/or immunohistochemistry. At present the use of conventional techniques to quantify RNA and/or protein corrected for the tissue base derived from the development profiles presented in this study, offers the most convenient way to measure protein and/ or RNA levels during development.

\section{References}

Bai S, Campbell Se, Moore JA, Morales mC, Gerdes AM, 1990. Influence of age, growth and sex on cardiac myocyte size and number in rats. Anatom Rec 226: 207-212.

Bishop SP, 1990. The myocardial cell: Normal Growth, cardiac hypertrophy and response to injury. Toxicol Pathol 18: 438-453.

BugaISKI L, ZAK R, 1979. Cellular growth of cardiac muscle after birth. Texas Rep Biol Med 39: 123-138.

Burton K, 1956. A study of the conditions and mechanisms of the diphenylamine reaction for the colorimetric estimation of deoxyribonucleic acids. Biochem J 62: 315-322.

Canale ED, Campbell GR, Smolich JJ, Campbell JH, 1986. Handbook of microscopic anatomy. Volume II/ 7: Cardiac Muscle. Springer-Verlag: Berlin Heidelberg. Chirgwin JM, Przybyla AE, MacDonald J, Rutter WJ, 
1979. Isolation of biologically active ribonucleic acid from sources enriched in ribonuclease. Biochemistry 18: 5294-5299.

Church GM, Gilbert W 1984. Genomic sequencing. Proc Natl Acad Sci USA 81: 1991-1995.

Claycomb WC, 1992. Control of cardiac muscle division. Trends Cardiovasc Med 2: 231-236.

Clubb JR FJ, Bishop SP, 1984. Formation of binucleated myocardial cells in the neonatal rat. Lab Invest 50: 571-577.

Farhadian F, Barrieux A, Lortet S, Marotte F, Oliviero P, RAPPAPORT L, SAMUEL J-L, 1994. Differential splicing of fibronectin pre-messenger ribonucleic acid during cardiac ontogeny and development of hypertrophy in the rat. Lab Invest 71: 552-559.

Feinberg AP, Vogelstein B, 1984. A technique for radiolabeling DNA restriction endonuclease fragments to high specific activity. Anal biochem 137: 266-267.

Gerdes AM, Moore JA, Hines JM, KirkLANd PA, Bishop SP, 1986. Regional differences in myocyte size in normal rat heart. Anatom Rec 215: 420-426.

Grajek S, Lesiak M, Pyda M, Zajac M, Paradowski St, KACZMAREK E, 1993. Hypertrophy and hyperplasia in cardiac muscle. Post-mortem human morphometric study. European Heart J 14: 40-47.

Grove D, NAIR KG, ZAK R, 1969. Biochemical correlates of cardiac hypertrophy III. Changes in DNA content: the relative contribution of polyploidy and mitotic activity. Circ Res 25: 463-471.

HANNAN RD, RothbLum LI, 1995. Regulation of ribosomal DNA transcription during neonatal cardiomyocyte hypertrophy. Cardiovasc Res 30: 502-510.

Houssaint E, Speich M, Le Douarin G, 1971. Evolution de la teneur en glycogène du coeur de l'embryon de poulet au cours de développement. Comptes rendus 273 Séries D: 189-192.

Jonker A, De Boer PAJ, van den Hoff MJB, Lamers WH, MoORMAN AFM, 1997. Towards quantitative in situ hybridization. J Histochem Cytochem 45: 413-423.

Kajstura J, Zhang X, Reiss K, Szoke E, Li P, Lagrasta C, Cheng W, Darzynkiewicz Z, Olivetti G, Anversa P, 1994. Myocyte cellular hyperplasia and myocyte cellular hypertrophy contribute to chronic ventricular remodeling in coronary artery narrowing-induced cardiomyopathy in rats. Circ Res 74: 383-400.

LOMPRÉ AM, LAMBERT F, LAKATTA EG, SchWARTZ K, 1991. Expression of sarcoplasmic reticulum $\mathrm{Ca}^{2+}$-ATPase and calsequestrin genes in rat heart during ontogenic development and aging. Circ Res 69: 1380-1388.

Mendez RE, Pfeffer JM, Ortolí FV, Bloch KD, Anderson S, Siedman JG, Brenner BM, 1987. Atrial natriuretic peptide transcription, storage and release in rats with myocardial infarction. Am I Physiol 253: H1449H1455.

MoOrman AFM, De Boer PAJ, Vermeulen JLM, LAMers WH, 1993. Practical aspects of radio-isotopic in situ hybridization on RNA. Histochem J 25: 251-266.

Moorman AFM, Vermedlen JLM, Koban MU, SchwartZ K, Lamers WH, Boheler KR, 1995. Patterns of expression of sarcoplasmic reticulum $\mathrm{Ca} 2+$-ATPase and phospholamban mRNAs during rat heart development. Circ Res 76: 616-625.

MunRo NH, 1966. The determination of nuclei acids. Method Biochem Anal 14: 113-176.

Olivetti G, Ricci R, Anversa P, 1987. Hyperplasia of myocyte nuclei in long-term cardiac hypertrophy in rats. J Clin Invest 80: 1818-1821.

Quaini F, Cigola E, Lagrasta C, Saccani G, Quaini E, Rossi C, Olivetti G, Anversa P, 1994. End-stage cardiac failure in humans is coupled with the induction of proliferating cell nuclear antigen and mitotic division in ventricular myocytes. Circ Res 75: 1050-1063.

RAKusAN K, 1984. Cardiac growth, maturation and aging. In Zak R (ed.). Growth of the heart in health and disease. New York: Raven, 25-40.

Rakusan K, TureK Z, 1985. Protamine inhibits capillary formation in growing rat hearts. Circ Res 57: 393-398.

Rockman HA, Ono S, Ross RS, Jones LR, Karimi M, Bhargava V, Ross J, Chien KR, 1994. Molecular and physiological alterations in murine ventricular dysfunction. Proc Natl Acad Sci USA 91: 2694-2698.

RuMYANTSEv PP, 1964. DNA synthesis and nuclear division in embryonal and postnatal histogenesis of myocardium (autoradiographic study). Arkh Anat Gistol Embriol 47: 59 (in Russian) in Fed Proc 1965, 24 (Translated suppl): T899-T902.

RuMYANTSEV PP, 1977. Interrelations of the proliferation and differentiation processes during cardiac myogenesis and regeneration. Int Rev Cytol 51: 197-273.

SAMbrooK J, Fritsch EF, Maniatis T, 1989. Molecular cloning: a laboratory manual, 2nd edn. New York: Cold Spring Harbor Laboratory.

Sasaki R, Watanabe Y, Morishita T, Yamagata S, 1968. Determination of deoxyribonucleic acid content of heart muscle and myocardial growth in normal rats. Tohoku J Exp Med 95: 185-192.

Sasaki R, Morishita T, Yamagata S, 1970a. Autoradiographic studies on heart muscle cells in normal rats. Tohoku J Exp Med 100: 1-13.

Sasaki R, Morishita T, Yamagata S, 1970b. A method for determining deoxyribonucleic acid synthetic time and mitotic time of heart muscle by autoradiographic technique. Tohoku J Exp Med 100: 15-21.

Schwartz K, Chassagne C, Boheler KR, 1993. The molecular biology of heart failure. JACC 22: 30A-33A.

Siddio T, Richardson PJ, Preedy VR, 1993. Optimum conditions for the assay of cardiac RNA: comparative content and effect of hyptertension. Biochem Med Metabol Biol 49: 149-163.

SoONPA MH, FieLd LJ, 1994. Assessment of cardiomyocyte DNA synthesis during hypertrophy in adult mice. Am J Physiol 266: H1439-H1445.

Stalsberg H, 1969. Regional mitotic activity in the precardiac mesoderm and differentiating heart tube in the chick embryo. Dev Biol 20: 18-45.

THOMPSON RP, LINDROTH JR, Wong Y-MM, 1990. Regional differences in DNA-synthetic activity in the preseptation myocardium of the chick. In: Clark E, Takao A (eds). Developmental cardiology: Morphogenesis and function. Mt. Kisco: Futura Publishing Co., 219-234.

Thompson RP, Kanai T, Germroth PG, Gourdie RG, Thomas PC, Barton PJR, Mikawa T, Anderson RH, 1995. In: Clark EB, Markwald RR, Takao A (eds). Developmental mechanisms of heart disease. Armonk, NY: Futura Publishing Co., 269-279.

Tuganowski W, Samek D, Glenc F, 1975. Glycogen content in human embryonic heart. Rec Adv Cardiac Struct Metab 8: 179-180.

ZAK R, 1973. Cell proliferation during cardiac growth. Am J Cardiol 31: 211. 